GEOSPORT FOR SOCIETY
$\begin{gathered}\text { GEOSPORT } \\ \text { SOCIETY }\end{gathered}$
Scientific Journal founded in 2014 under aegis of University of Oradea (Romania),
University of Debrecen (Hungary), University of Gdánsk (Poland)
ISSN 2393-1353
Edited by Oradea University Press
1, University Street, 410087, Oradea, Romania
Journal homepage: http://geosport.uoradea.ro/geosport.html

\title{
The spatial characteristics of the infrastructural background of physical education (PE) classes in Hungarian kindergartens
}

\author{
Gábor KOZMA ${ }^{1 *}$ \\ 1. University of Debredcen, Faculty of Science and Technology, Department of Social Geography and Regional \\ Development Planning, Egyetem square 1, 4032, Debrecen, Hungary, e-mail: kozma.gabor@science.unideb.hu \\ * Corresponding author
}

Citation: KOZMA, G. (2020). The spatial characteristics of the infrastructural background of physical education (PE) classes in Hungarian kindergartens. Geosport for Society, 12(1), 13-23. https://doi.org/10.30892/gss.1202-054

Article history: Received: 17.12.2019; Revised: 05.01.2020; Accepted: 22.01.2020, Available online: 05.02.2020

\begin{abstract}
Kindergarten physical education (PE) plays an important role in the development of the age group concerned for a number of reasons; however, it is only possible in case of certain infrastructural conditions, which make it possible to have PE classes even in case of unfavourable weather conditions. In the spirit of the above, the primary objective of this paper is the examination of the spatial distribution of these facilities (smaller gym rooms and larger gyms) used for kindergarten PE classes in Hungary. The following could be emphasised from the research findings. Firstly, the infrastructural conditions of kindergarten PE are not very favourable in Hungary: hardly more than $50 \%$ of all institutions have suitable infrastructure. Secondly, from among the factors influencing the spatial distribution of the available facilities, at both the district and the settlement levels, the size of the population can be considered as particularly important: as the population size increases, an improvement of the conditions can be seen. Thirdly, the level of economic development hardly has any influence on their position.
\end{abstract}

Keywords: kindergarten, physical education, Hungary, spatial characteristics

\section{Introduction}

Kindergarten PE plays an important role in the development of the age group concerned for a number of reasons (Csányi, 2011; Lemos et al., 2012; McEvilly et al., 2013; Rétsági and Ekler, 2011; Temple, 2016; Végvári, 2013; Wiebelhaus and FryerHanson, 2016). Firstly, by way of getting children to enjoy regular physical activity, it promotes a healthy lifestyle and a lifelong desire for engaging in sports; secondly, it contributes to the locomotor development of children. Thirdly, by establishing good 
and preventing bad posture, it also has a positive effect on the later life/health condition of the children.

In the light of the above, it is hardly surprising that in Hungary Government Decree 363/2012 (XII. 17.) on the national basic programme of kindergarten education also devotes attention to this issue. Even though the words "sport" or "physical education" are not used in the above mentioned provision of law, in the chapter titled "Forms of activity in kindergarten and the tasks of kindergarten teachers", the sub-chapter titled "Physical activities" discusses in detail the advantages and positive consequences of physical activity.

The high-quality organization of kindergarten $\mathrm{PE}$, however, requires proper infrastructural conditions. In the spring and autumn months, in case of dry weather, the outdoor playground of the kindergarten offers good opportunities, with the advantages of physical activities performed outdoors, as well as the availability of more diverse and flexible conditions (Balogh, 2015). On days of rain or other precipitation, as well as in winter, however, when it is not possible to dress up the children every time in suitable clothes, the most optimum place to satisfy kindergarteners' need for physical activity is a dedicated gym (the conversion of normal kindergarten classrooms for this purpose is very time consuming, and still does not offer optimal conditions). In the spirit of the above, Schedule 2 to Ministerial Decree 20/2012 (VIII. 31.) EMMI on the operation of institutions of education and teaching, as well as the names used by institutions of public education (LIST of mandatory (minimum) items and equipment to be available at institutions of education and training), in kindergartens (in case of units consisting of several institutions, at each site), it is required to have, in addition to the playground/courtyard, also a gym room with equipment storage (the required equipment includes gymnastic benches, mats and wall bars).

At the same time, the examination of this issue also offers some conclusions from a geographical perspective, since the facilities concerned can be regarded as a type of those sports facilities the spatial distribution of which has become an important area of research in the field of sports geography, a sub-discipline of increasing significance (Bánhidi, 2011; Ilies et al., 2014; Kozma, 2014; Wise and Kohe, 2020). The analyses conducted in this topic yielded quite varied results. According to the results of a survey of the situation in Scandinavian countries (Rafoss and Troelsen, 2010), rural areas have better results in relative terms (per capita) than urban areas; at the same time, in terms of facilities appearing in the 1990s (e. g. fitness centres, ice rinks, multifunctional activity centres), which make different forms of physical activity possible than before, the advantage of cities and more densely populated areas is quite clear.

A research project exploring the conditions in the Netherlands (Hoekman et al., 2016) yielded partly similar and partly different results. On the one hand it was also 
clearly shown by this study that with the decreasing level of urbanization, the relative (number per 10,000 inhabitants) value of the sports facilities was increasing (at the same time, the average distance from these facilities was much lower in urban areas); on the other hand, in terms of the how widespread certain types of sports facilities (e.g. fitness centres, golf courses, sport halls, swimming pools) are, no major differences could be established between the rural and the urban areas.

A Canadian research project that looked at conurbations pointed out, on the one hand, that the relatively higher value of large cities is followed by a lower value in the first suburban zone, while more distant suburbs once again have a higher value (O'Reilly et al., 2015). On the other hand, differences could also be observed in terms of the quality characteristics (e.g. number of parking spots, number of change rooms, quality of services) of the facilities: while relatively less attractive facilities are typical in larger cities (primarily due to these facilities being of older construction), followed by higher values in the first suburban zone, and then by somewhat lower values in the second zone, which were nonetheless better than those in the large cities themselves.

In the spirit of the above, the primary objective of this paper is the examination of the spatial distribution of the facilities used for kindergarten PE classes in Hungary to find out which districts/settlements offer the worst conditions for children, and to what factors this unfavourable situation may be traced back. Due to the facts outlined in the previous paragraph, in the course of the research project, special attention has been given to the analysis of the availability of gym rooms and dedicated gyms.

\section{Methodology}

In the course of the research, the most important source was the Public Education Information System (KIR) database operated by the Educational Authority, from which data related to sports infrastructure at each kindergarten, in a breakdown according to campus, or "place of task performance", to use the official terminology) could be obtained for January 2019 (does it have a gym room, a gym, a swimming pool and/or a sports track). The database also included information on the capacities of the individual units, as well as the actual number of children enrolled (hereinafter, the word "kindergarten" will mean a "place of task performance" of a kindergarten). In addition, I have also reviewed the pedagogical programmes of the kindergartens, and through their use made the data more accurate. The database thus generated included 4,586 kindergartens, and these data were analysed with the use of Excel and IBM SPSS Statistics 23 software.

\section{Results}

In general, the analysis of the data revealed a rather unfavourable situation (table 1). Only slightly more than half of the kindergartens operating in January 2019 
had infrastructure serving the purpose of physical education; however, a positive finding, someone counterbalancing the above, was that these units represent nearly $2 / 3$ of both the capacities and the actual number of children in these kindergartens. From among the individual infrastructural elements, gym rooms were available in most kindergartens, followed by full-scale gyms and sports tracks (the difference between a gym room and a gym is fundamentally in size: on the basis of standard no. MSZE 24203-2:2012 currently in effect, a facility of $225 \mathrm{~m}^{2}$ is still considered a halfsized gym). The least frequently available infrastructural elements are swimming pools; of the 4,586 institutions, only 33 institutions had such a facility.

Table 1. The availability of physical education infrastructural elements at kindergartens, on the basis of different criteria (certain elements may be simultaneously available in a kindergarten, \%)

Source: KIR database of the Educational Authority

\begin{tabular}{|c|c|c|c|c|c|}
\hline & $\begin{array}{c}\text { existing physical education } \\
\text { infrastructural element }\end{array}$ & gym room & gym & $\begin{array}{c}\text { sport } \\
\text { track }\end{array}$ & $\begin{array}{c}\text { swimmin } \\
\text { g pool }\end{array}$ \\
\hline number of kindergartens & 56.32 & 43.35 & 14.52 & 4.43 & 0.72 \\
\hline capacity of kindergartens & 65.50 & 47.62 & 19.71 & 5.59 & 0.74 \\
\hline actual number of children & 65.10 & 47.28 & 19.06 & 4.69 & 0.69 \\
\hline
\end{tabular}

In case of the three least frequently available facilities, it can be clearly observed that they are typically linked to larger public education institutions (table 2): in all three cases, the proportion of institutions that also include a school alongside a kindergarten was much higher. What we can find in the background of this fact, in case of gyms and sports tracks, is that in the interest of satisfying the needs of schoolchildren (as well as the statutory requirements), it is necessary to establish such facilities, and once they are available - at certain occasions - kindergarteners can also use them.

Table 2. The percentage of institutions including a kindergarten and a school and a kindergarten only that have the three less frequently available PE facilities (\%)

Source: KIR database of the Educational Authority

\begin{tabular}{|c|c|c|}
\hline & $\begin{array}{c}\text { institution including a } \\
\text { kindergarten and school }\end{array}$ & $\begin{array}{c}\text { institution operating as a } \\
\text { kindergarten only }\end{array}$ \\
\hline share within all kindergartens & 3.10 & 96.90 \\
\hline $\begin{array}{c}\text { share within kindergartens with a } \\
\text { gym }\end{array}$ & 14.86 & 85.14 \\
\hline $\begin{array}{c}\text { share within kindergartens with } \\
\text { sports tracks }\end{array}$ & 44.83 & 55.17 \\
\hline $\begin{array}{c}\text { share within kindergartens with a } \\
\text { swimming pools }\end{array}$ & 18.18 & 81.82 \\
\hline
\end{tabular}

In the course of the research of the territorial characteristics - for the reasons mentioned in the Introduction (e.g. statutory requirement) - special attention was devoted to the availability of gym rooms and gyms (in the following, the concept of facilities serving the purpose of kindergarten PE activities refers to these facilities). 
According to the data $55.9 \%$ of all kindergartens had such facilities, which institutions represent $65 \%$ of all kindergarten places (in terms of capacities) and $64.6 \%$ of the number of kindergarteners. The above - already not very positive - values are further deteriorated by the fact that without the data of Budapest, the city with the best indicators (see below), the above numbers would be the following: $53.3 \%$ of all kindergartens, $62.1 \%$ of kindergarten places and $61.6 \%$ of kindergarteners.

If we analyse the data on the level of counties (figure 1), a clear tendency cannot be observed: counties with the lowest and those with the highest levels also have territorial units that are in the category of more economic and social development, as well as areas that are lagging behind.

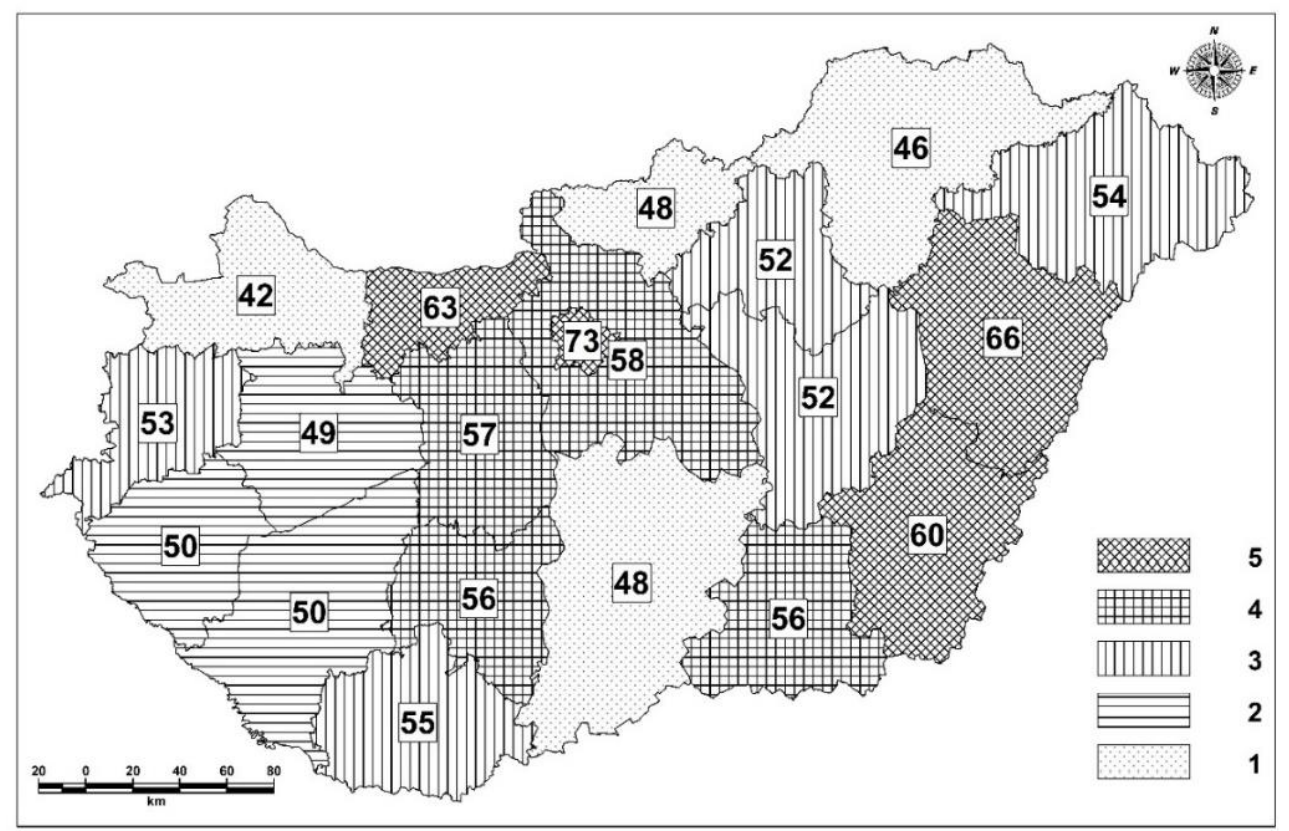

Figure 1. The proportion of kindergartens having facilities of PE activities, on the county level, in January 2019

1: - 48\%, 2: 49-51\%, 3: 52-55\%, 4: 56-59\%, 5: 60\%Source: KIR database of the Educational Authority

The next territorial level of the research project was administrative districts, in Hungarian terms "járás" (in this case, Budapest was excluded). The analysis of the location of PE (figure 2) facilities once again could not be used for drawing a clear conclusion: districts with the lowest as well as with the highest values are located scattered across the country.

Establishing the given facilities requires an investment of a certain amount; therefore, the question may arise to what extent the availability of such facilities is 
influenced by the social-economic development of the district. On the basis of the data, the effect of this factor cannot be regarded as too strong. On the one hand, after putting the districts in 10 categories based on this factor (table 3) it can be seen that with the increasing level of development, the proportion of kindergartens with PE facilities only increases to a very small extent. This same fact is also reinforced by the result of calculating the correlation (figure 3): in case of the exponential correlation showing the strongest link, the value of $\mathrm{R}^{2}$ is 0.0445 , which suggests a rather relationship.

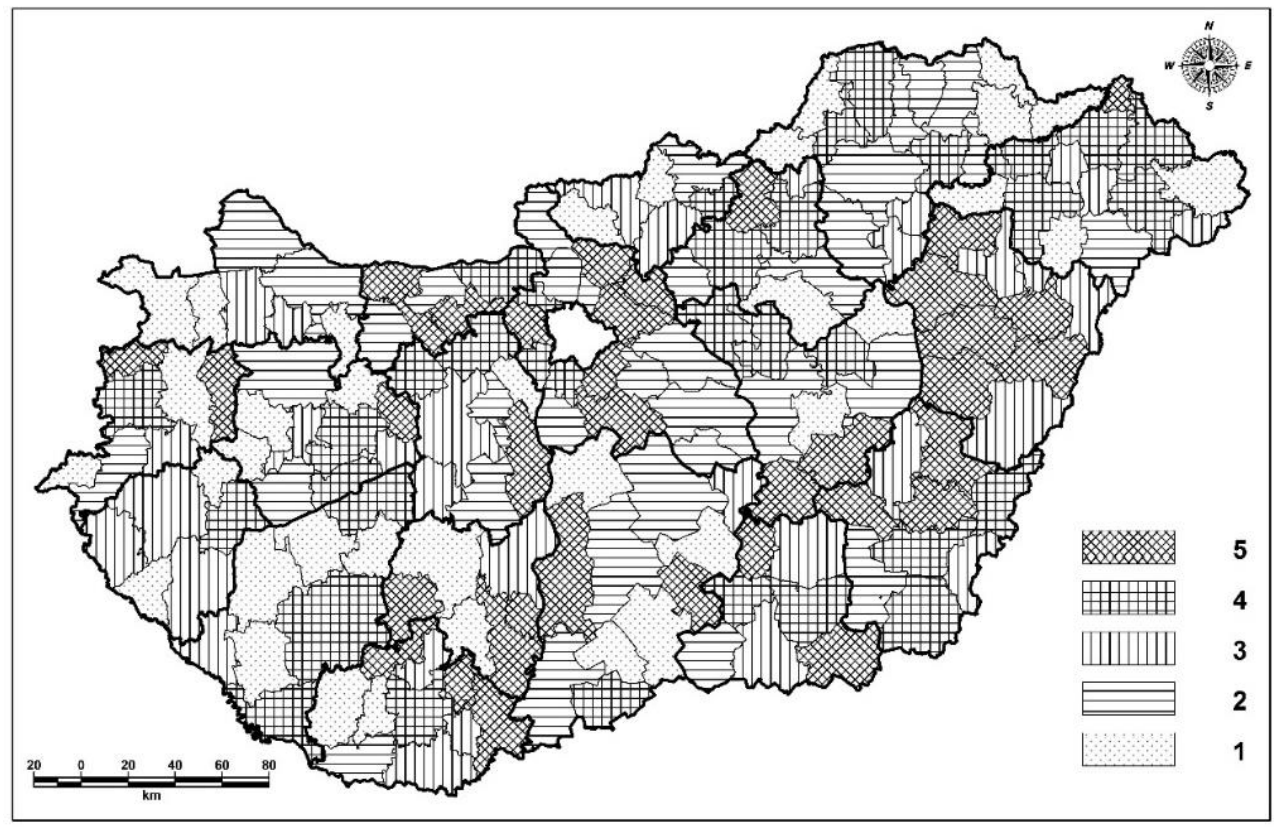

Figure 2. The proportion of kindergartens having facilities of PE activities, on the administrative district level, in January 2019 1: - 39\%, 2: 40-49\%, 3: 50-55\%, 4: 56-66\%, 5: 67\%Source: KIR database of the Educational Authority

Table 3. The relationship between the development of the district and the availability of kindergarten PE facilities Source: KIR database of the Educational Authority, 290/2014. (XI. 26) on the classification of beneficiary districts

\begin{tabular}{|l|c|}
\hline the development of the districts & $\begin{array}{c}\text { the proportion of kindergartens } \\
\text { with PE facilities (\%) }\end{array}$ \\
\hline first decile & 44.3 \\
\hline second decile & 56.8 \\
\hline third decile & 45.1 \\
\hline fourth decile & 51.7 \\
\hline fifth decile & 48.0 \\
\hline sixth decile & 53.5 \\
\hline seventh decile & 51.9 \\
\hline eighth decile & 51.3 \\
\hline ninth decile & 61.5 \\
\hline tenth decile & 57.2 \\
\hline
\end{tabular}




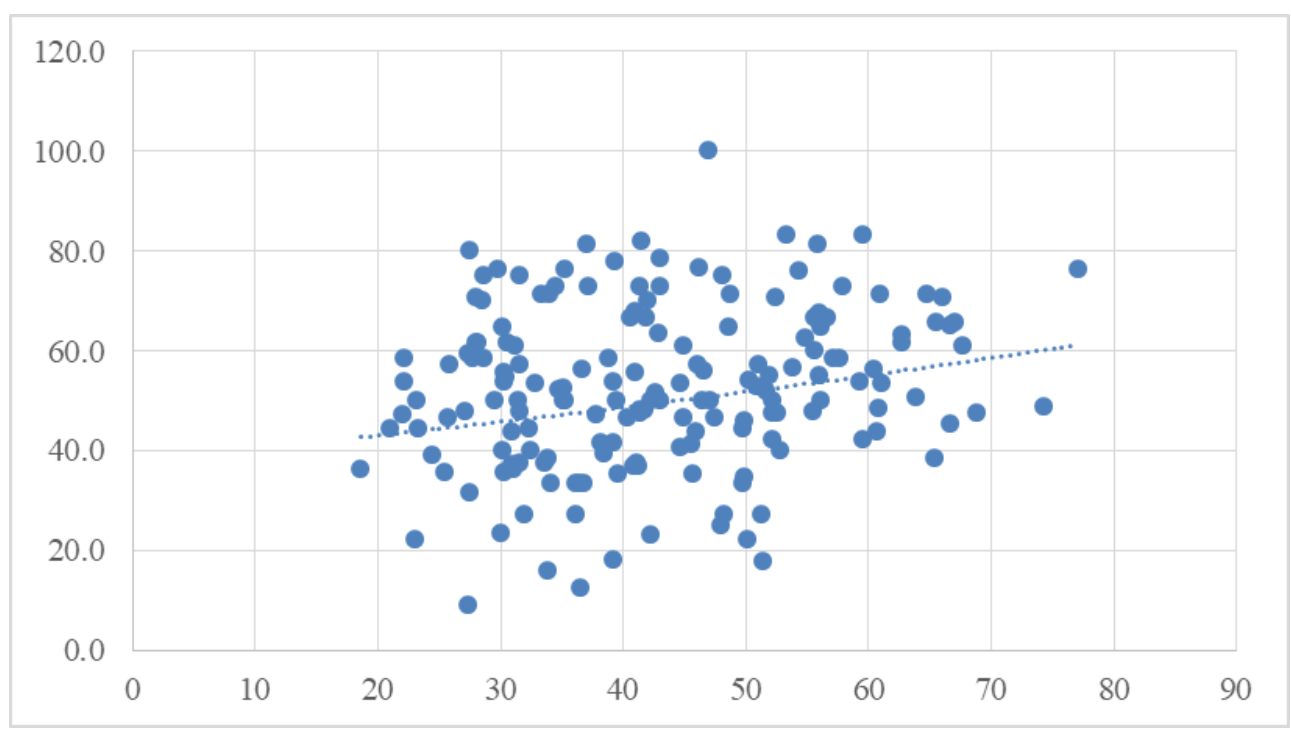

Figure 3. The relationship between the development of the district and the availability of kindergarten PE facilities ( $x$ axis: complex value of administrative districts, $y$ axis: the proportion of kindergartens with PE facilities - \%) Source: KIR database of the Educational Authority, 290/2014. (XI. 26.) on the classification of beneficiary districts

Table 4. The relationship between the average population size of districts and the proportion of kindergartens with PE facilities

Source: KIR database of the Educational Authority, National Territorial Development and Spatial Planning Information System

\begin{tabular}{|l|c|}
\hline $\begin{array}{l}\text { average number of settlements of administrative } \\
\text { districts }\end{array}$ & $\begin{array}{c}\text { the proportion of kindergartens } \\
\text { with PE facilities (\%) }\end{array}$ \\
\hline less than 1,000 inhabitants & 43.2 \\
\hline $1,000-1,500$ inhabitants & 48.5 \\
\hline $1,500-2,000$ inhabitants & 53.2 \\
\hline $2,000-3,000$ inhabitants & 53.9 \\
\hline $3,000-4,000$ inhabitants & 55.6 \\
\hline $4,000-5,000$ inhabitants & 57.3 \\
\hline $5,000-10,000$ inhabitants & 55.1 \\
\hline more than 10,000 inhabitants & 60.5 \\
\hline
\end{tabular}

Another perspective of the settlement-level examination of districts was population. According to the data, a stronger link can be observed in this respect, as the proportion of kindergartens with PE facilities was higher in case of districts with larger populations (table 4). The result of the correlation calculation also reinforces this fact: the value of $\mathrm{R}^{2}$ in case of the logarithmic correlation showing the strongest link is 0.1162 (figure 4).

In the course of the settlement-level analyses, we examined the effect of the two factors mentioned above (population size and level of development). From the point of view of the former, the interrelationship can be seen quite clearly (table 5): in case of bigger settlements, the conditions of kindergarten PE are also better. Values below the national average (55.9\%) can only be observed in case of settlements with 
populations below 2000, while the worst access to such facilities was found in case of settlements with less than 1000 residents.

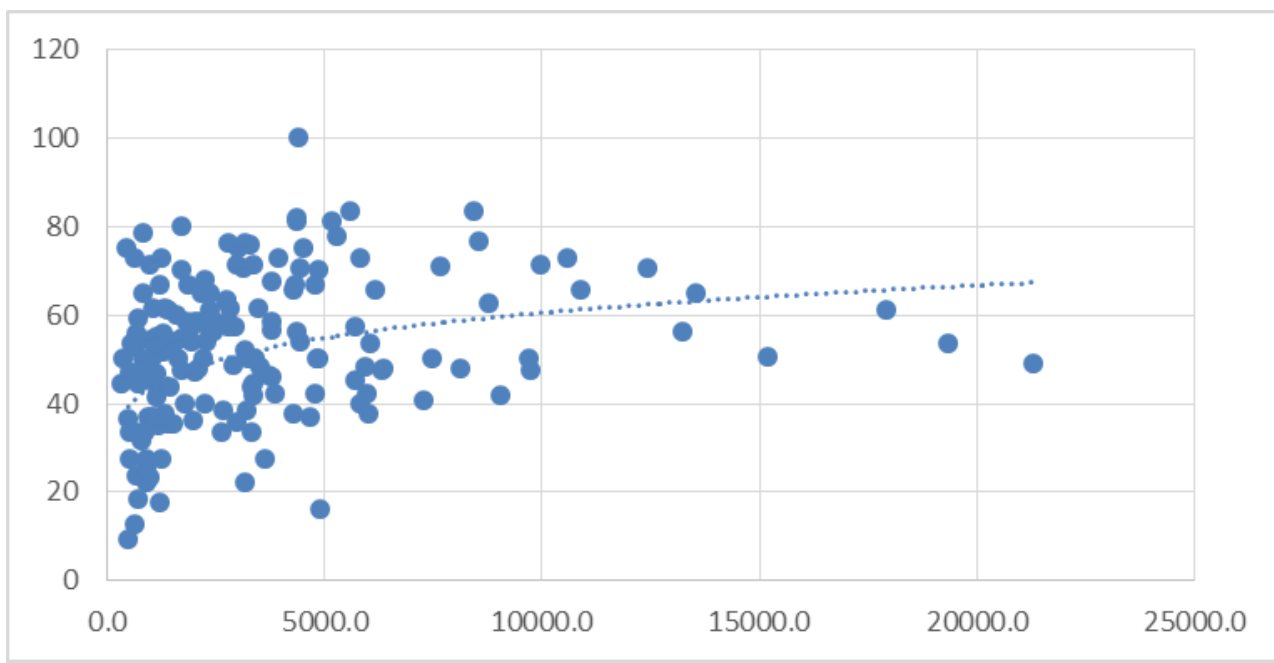

Figure 4. The relationship between the population of the districts and the number of kindergarten PE facilities (the figure does not include the values for the Debrecen district ( $x-107350 ; y-71,2)$, because it would have significantly distorted the diagram)

(axis $\mathrm{x}$ - the number of people per settlement in the district, axis $\mathrm{y}$ - the proportion of kindergartens with facilities for PE activities - \%)

Source: KIR database of the Educational Authority, National Territorial Development and Spatial Planning Information System

Table 5. The relationship between the number of inhabitants of settlements and the proportion of kindergartens with PE facilities

Source: KIR database of the Educational Authority, National Territorial Development and Spatial Planning Information System

\begin{tabular}{|l|c|}
\hline number of inhabitants of settlements & $\begin{array}{c}\text { the proportion of kindergartens } \\
\text { with PE facilities (\%) }\end{array}$ \\
\hline less than 500 inhabitants & 31.6 \\
\hline $501-1,000$ inhabitants & 34.2 \\
\hline $1,001-1,500$ inhabitants & 47.7 \\
\hline $1,501-2,000$ inhabitants & 54.3 \\
\hline $2,001-3,000$ inhabitants & 57.2 \\
\hline $3,001-5,000$ inhabitants & 61.2 \\
\hline $5,001-10,000$ inhabitants & 56.0 \\
\hline $10,001-15,000$ inhabitants & 64.0 \\
\hline $15,001-20,000$ inhabitants & 64.5 \\
\hline $20,001-30,000$ inhabitants & 61.2 \\
\hline $30,001-50,000$ inhabitants & 66.5 \\
\hline $50,001-100,000$ inhabitants & 65.0 \\
\hline more than 100,000 inhabitants & 56.9 \\
\hline Budapest & 72.7 \\
\hline
\end{tabular}

If we examine the effect of the settlements' level of development, a clear relationship cannot be established (table 6): from among the eight categories of population size, beneficiary (i.e. less developed) settlements have better access in case 
of three groups and worse access in case of five groups, which means that neither a positive, nor a negative relationship can be identified.

Table 6. The relationship between the level of development of settlements and the proportion of kindergartens with PE facilities

Source: KIR database of the Educational Authority, Government Decree 105/2015. (IV. 23.) on the classification of beneficiary districts and the conditions of classification

\begin{tabular}{|l|c|c|}
\hline $\begin{array}{l}\text { number of inhabitants of } \\
\text { settlements }\end{array}$ & $\begin{array}{c}\text { the proportion of } \\
\text { kindergartens with PE } \\
\text { facilities (\%) }\end{array}$ & $\begin{array}{c}\text { the proportion of kindergartens with PE on } \\
\text { beneficiary settlements in the given category } \\
\text { of population size (\%) }\end{array}$ \\
\hline less than 500 inhabitants & 31.6 & 33.6 \\
\hline $501-1,000$ inhabitants & 34.2 & 33.8 \\
\hline $1,001-1,500$ inhabitants & 47.7 & 51.5 \\
\hline $1,501-2,000$ inhabitants & 54.3 & 51.1 \\
\hline $2,001-3,000$ inhabitants & 57.2 & 60.0 \\
\hline $3,001-5,000$ inhabitants & 61.2 & 58.7 \\
\hline $5,001-10,000$ inhabitants & 56.0 & 48.5 \\
\hline $10,001-15,000$ inhabitants & 64.0 & 63.2 \\
\hline
\end{tabular}

The relationships outlined above (i.e. the more significant effect of the population size) can, in my opinion, be attributed, on the one hand, to the fact that the kindergartens of smaller settlements were built earlier, when the construction of PE facilities (gyms and gym rooms) was not yet an expectation. In addition, these are typically kindergartens of smaller capacities and actual enrolments, and consequently, from an economic point of view it is less worth making major investments in them. On the other hand, on larger settlements, there is a much higher proportion of kindergartens built in the past few decades (from the 1970s), in which case much more attention was devoted to the creation of conditions that would satisfy the need of the children for physical activity. The assumption formulated in the previous few sentences is also underlined by the results shown in table 7: the larger a kindergarten is, the more the conditions necessary for physical education are available in every season.

Table 7. The relationship between the size of kindergartens (number of places for children) and the availability of PE facilities

Source: KIR database of the Educational Authority

\begin{tabular}{|l|c|}
\hline $\begin{array}{l}\text { capacity of kindergartens (number of } \\
\text { places for children) }\end{array}$ & the proportion of kindergartens with PE facilities (\%) \\
\hline $0-25$ & 34.7 \\
\hline $26-44$ & 40.2 \\
\hline $45-50$ & 39.9 \\
\hline $51-64$ & 52.8 \\
\hline $65-75$ & 53.8 \\
\hline $76-90$ & 59.6 \\
\hline $91-100$ & 69.2 \\
\hline $101-125$ & 67.2 \\
\hline $126-150$ & 76.5 \\
\hline more than 150 & 79.7 \\
\hline
\end{tabular}


The next determining factor related to population size is the trend of the population change (table 8). In case of settlements where the population size increased in the 2010s, the proportion of kindergartens with PE facilities is higher, and this is particularly true for settlements with an increase of at least $20 \%$. In all likelihood, the above can be attributed to the fact that, in the interest of satisfying the needs arising with the increasing population size, new kindergartens were also built, in which the law already prescribed the creation of gyms/gym rooms.

Table 8. The relationship between the extent of population change on settlements between 2008 and 2018 and the availability of kindergarten PE facilities (the table does not include the values for Budapest).

Source: KIR database of the Educational Authority

\begin{tabular}{|c|c|}
\hline $\begin{array}{l}\text { the extent of population change between } 2008 \\
\text { and } 2018\end{array}$ & the proportion of kindergartens with PE facilities (\%) \\
\hline below $100 \%$ & $52.7 \%$ \\
\hline above $100 \%$ & $55.0 \%$ \\
\hline within that, above $110 \%$ & $57.3 \%$ \\
\hline above $120 \%$ & $65.2 \%$ \\
\hline
\end{tabular}

The smaller effect of the level of development on the levels of both the districts and the settlements can, in all likelihood, be attributed to the fact that the investments are realized decisively with the help of subsidies from the central budget, and therefore, the influence of the settlement's economic-financial position (which is closely linked to their level of social-economic development) is much smaller. In addition, a significant part of kindergarten developments realized in recent years with the use of EU grants were also implemented in beneficiary areas (districts and settlements).

\section{Conclusions}

The most important results of the study could be summarised as follows. The infrastructural conditions of kindergarten $\mathrm{PE}$ cannot be considered very favourable in Hungary: hardly more than $50 \%$ of the institutions have facilities that would make it possible to engage in physical activity also in case of bad weather. From among the factors influencing the spatial distribution of the given facilities, at both the district and the settlement levels, the size of the population can be considered as particularly important, while the level of economic development hardly has any influence on their position.

\section{Acknowledgements}

This study was supported by the EFOP-3.6.2-16-2017-00003 project which is financed by the European Union and the European Social Fund. 


\section{References}

Balogh, B., Bújdosóné-Papp, A., Fazekas, J., Lenkey-Tóth, P., Olvasztóné-Balogh, Zs., Pálfi, S., TamásiDsupin, B. \& Vargáné Nagy, A. (2015). Óvodapedagógiai módszertani kézikönyv [Handbook for methods in kindergartens], Debreceni Egyetem (in Hungarian)

Bánhidi, M. (2011). Sportföldrajz [Sport geography], Dialóg Campus Kiadó, Budapest - Pécs (in Hungarian)

Csányi, T. (2011). Az óvodai mozgásos tevékenységrendszer a 21. században I-II [Physical education in kindergartens in 21 th century]. Óvodai Nevelés, 64(9, 10), 8-11, 29-31 (in Hungarian).

Hoekman, R., Breedveld, K., \& Kraaykamp, G. (2016). A landscape of sport facilities in the Netherlands. International Journal of Sport Policy and Politics, 8(2), 305-320.

Ilies, A., Dehoorne, O., Wendt, J. \& Kozma, G. (2014). For Geography and Sport, Sport Geography or Geography of Sport. Geosport for Society, 1(1-2), 5-12.

Kozma, G. (2014). The spatial development of sports facilities within the cities: a Central European case study. Geosport for Society, 1(1-2), 13-20.

Lemos, A. G., Avigo, E. L., \& Barela, J. A. (2012). Physical education in kindergarten promotes fundamental motor skill development. Advances in Physical Education, 2(1), 17-21.

McEvilly, N., Atencio, M., Verheul, M., \& Jess, M. (2013). Understanding the rationale for preschool physical education: implications for practitioners' and children's embodied practices and subjectivity formation. Sport, Education and Society, 18(6), 731-748.

O'Reilly, N., Berger, I. E., Hernandez, T., Parent, M. M. \& Séguin, B. (2015). Urban sportscapes: An environmental deterministic perspective on the management of youth sport participation. Sport Managment Review, 18(2), 291-307.

Rafoss, K. \& Troelsen, J. (2010). Sports facilities for all? The financing, distribution and use of sports facilities in Scandinavian countries. Sport in Society, 13(4), 643-656.

Rétsági, E. \& H. Ekler, J. (2011). A testnevelés elmélet és a testnevelés módszertan alapjai [Basis of theoretical and practical aspects of physical education]. In (eds. by Rétsági, E. et al.) Sportelméleti ismeretek. Dialóg Campus Kiadó, Budapest - Pécs, 14-60.

Temple, V. A., Crane, J. R., Brown, A., Williams, B. L., \& Bell, R. I. (2016). Recreational activities and motor skills of children in kindergarten. Physical Education and Sport Pedagogy, 21(3), 268-280.

Végvári, Á. (2014) Az óvodai testnevelés szerepe az életen át tartó sportolás megalapozásában [Role of physical education in founding of life long sport activity]. Bsc-thesis, University of West Hungary (in Hungarian).

Wiebelhaus, S., \& Fryer-Hanson, M. (2016). Effects of classroom-based physical activities on off-task behaviors and attention: Kindergarten case study. The Qualitative Report, 21(8), 1380-1393.

Wise, N., \& Kohe, G. Z. (2020). Sports geography: new approaches, perspectives and directions, Sport in Society, 23(1), 1-10, 